\title{
Impact of Dividend Payout on Profitability of Consumer Goods Firm Quoted on Nigeria Stock Exchange
}

\author{
Onumoh Ahmed Yahaya \\ Federal College of Education (Technical) Gusau, Zamfara State
}

\begin{abstract}
The aim of this study is to find out the impact of dividend payout on profitability of consumer goods firm quoted on the Nigerian Stock Exchange over the past seven (7) years from 2008-2014. Profitability was measured using Return on Assets (ROA) and Return on Equity (ROE). The effects of dividend payout ratio on ROA and ROE were analyzed via longitudinal panel data. The study also employed a sub-sample in order to arrive at a profound conclusion with regard to the impact of dividend policy on corporate profitability. The results of the study revealed that there was a significant relationship between dividend payout and corporate profitability in terms of return on assets and return on equity. A positive significant relationship was found between dividend payout and return on assets on one hand and return on equity on the other hand. It was recommended that, as the ultimate objective of a corporate is to maximize shareholders' wealth hence the firm value, firm mangers should design and implement a dividend policy that will enhance the corporate profitability and shareholders wealth.
\end{abstract}

Keywords: Dividend Payout, Return on Assets, Return on Equity

DOI: $10.7176 /$ RJFA/10-11-06

Publication date: June $30^{\text {th }} 2019$

\section{Introduction}

Dividend decision has drawn momentous attention of the researchers. For more than half a century, the dividend policy remains an unsettled yet puzzling topic in the finance literature. Notwithstanding, several theories and models have been developed regarding the dividend policy, yet the corporate dividend policy is still an unresolved and controversial issue. Dividend payout is the amount of cash that a company pays to its shareholders in the form of dividends. The company can decide to send all the profits back to its shareholders or investors or keep a portion of it as retained earnings. Healthy dividends payouts thus indicate that companies are generating real earnings rather than cooking books (Enekwe, Nweze, \& Agu, 2009).

The payment of dividend to shareholders depends to a great deal on the financial performance of companies. Abdullah and Thafani (2014), Ajanthan (2013) and Gill et al (2010) noted that current and past years' profits are important factors in influencing dividend payments. Firm's ability to continually post good profits is in a better position to pay dividends to their shareholders. Dividends signaling theory prescribes that dividend payout can be used as a device to communicate information about a company's financial performance to investors. Cash dividend announcement convey valuable information which shareholders do not have about management's assessment of a firm's future profitability, thus reducing information asymmetry.

The traditional view of the dividend decision states that at a particular time the amount of cash paid today as dividend is more valuable than the retained cash. The traditional view argues that paying early dividends may not change the corporation risk level but it will change the perception of the investor about the corporation's risk level thus dividends are more valuable than retained earnings (Abdullah \& Thafani, 2014).

Based on the literature, there are divergent views on whether dividend payout ratio affects Return on Assets (ROA) and Return on Equity (ROE) or not, and most of the studies reviewed are conducted in developed countries. The results of this study will also serve as a data base for further researchers in this field. Consequently, this paper investigates the influence of dividend payout ratio of supplied consumer goods manufacturing firms listed in Nigeria stock exchange to ROA and ROE. As guided by literature, dividend payout is independent variable with retained earnings per share and growth as control variables.

The paper is organized as follows: section one is the introduction, section two reviews the related studies and theoretical frame work, section three discusses the research methodology, section four discusses the results, conclusions and recommendation are drawn in section five.

\section{Review of Literature}

Dividend is that portion of net profits which is distributed among the shareholders. The dividend decision of the firm is of crucial importance for the finance manager since it determines the amount to be distributed among shareholders and the amount of profit to be retained in the business. Retained earnings are very important for the growth of the firm. Shareholders may also expect the company to pay more dividends. So both the growth of company and higher dividend distribution are in conflict. So the dividend decision has to be taken in the light of wealth maximisation objective. This requires a very good balance between dividends and retention of earnings.

Walter's Model (Dividend Relevant Theory) 
Prof. James E Walter argues that the choice of dividend payout ratio almost always affects the value of the firm, it is considered as relevant. In that case, a change in the dividend payout ratio will be followed by a change in the market value of the firm. If the dividend is relevant, there must be an optimum payout ratio. Optimum payout ratio is that ratio which gives highest market value per share (makemynote.weeby.com)

A company's dividend decision may signal what management believes is the future prospect of the firm and its stock price. A model developed by Miller and Rock (1985) suggests that dividend announcements convey information to investors regarding the firm's future prospects. Many earlier studies had shown that stock prices tend to increase when an increase in dividends is announced and tend to decrease when a decrease or omission is announced. They pointed out that this is likely due to the information content of dividends.

Enekwe, Nweze and Agu (2009) critically studied the effect of dividend payout on performance evaluation of quoted cement companies in Nigeria over the past twelve (12) years period from 2003 to 2014. The study outcome revealed that the profitable firms tend to disburse more dividends. They have found a positive association between the dividend payout ratio, cash flows, and profitability. This is in line with Musiega et al (2013), Sarhandi et al (2015), Khan (2012) and Robert and Venette (2009). In a research conducted in the United State, Gill et al. (2010) investigated the determinant of dividend payout ratios in American service and manufacturing firms and found that the dividend payout ratio is a function of profit margin and sales growth among other factors. For the services industry, the dividend payout ratio was found to be a function of profit margin, sales growth, and debt-toequity ratio. For manufacturing firms, the dividend payout ratio was found to be a function of profit margin, tax and market-to-book value. Similarly Okparaand Chigozie (2010) analyzes the determinants of dividend payouts in Nigeria. The authors used regression statistical technique to analysis factors that influence dividend payout in Nigeria. They pointed out that the current ratio, profitability and dividends for the previous year are very important determinants of dividend payout. Rehman and Takumi (2012) in their study examines the determinants of dividend payout ratio in the largest stock exchange of Pakistan i.e. Karachi Stock Exchange (KSE) for 50 companies that announced dividend in 2009. The study documents positive relation of debt to equity ratio, profitability, current ratio and corporate tax with dividend payout ratio while operating cash flow per share and market to book value ratio has a negative relationship with dividend payout ratio. Relationship between profitability and dividends payout ratio suggested that companies with higher profit are more likely to pay dividends. Malik et al (2013) discover that dividend paid at appropriate time has a positive impact on reputation of company. Corporate dividend paying companies in Pakistan are very low as compared to other emerging economies.

Ajanthan (2013) investigates the relationship between dividend payout and firm profitability among listed hotels and restaurant companies in the Colombo Stock Exchange (CSE). Regression and correlation analysis were carried out to establish the relationship between dividend payout and firm profitability. The findings indicated that dividend payout was a crucial factor affecting firm performance $\left(R=0.725 \& R^{2}=0.526\right)$. Their relationship was also strong and positive. The author concluded that based on the findings that dividend policy is relevant and suggested that managers should pay attention and devote adequate time in designing a dividend policy that will enhance firm profitability and therefore shareholder value.

The relationship between dividend payout ratio and profitability of a firm was conducted in Pakistan using energy and textile sector. The study covers a time span of 1996-2008. The results of logarithmic regression showed that no matter what industry is, there is a negative impact of dividend payout ratio on next year profitability of a firm (Hasan et al, 2015). Abdullah and Thafani (2014) sought to establish the relationship between dividend payout on corporate profitability in the Manufacturing Companies listed on Colombo Stock Exchange in Sri Lanka during the period of 2007 - 2011. The study also employed a sub-sample in order to arrive at a profound conclusion with regard to the impact of dividend policy on corporate profitability. They found that constant dividend payout has positive association with return on assets and return on equity as far as the dividend paying sample is concerned. Lie (2005) argued that firms that increase payouts have excess financial flexibility and exhibit positive concurrent income shocks and decreases in income volatility, but there is limited evidence of subsequent performance improvements in his article "Financial flexibility, performance, and the corporate payout choice". He stated that firms that increase payouts have lower past volatility of operating income than other firms. This can be explained by the fact that managers increase the firms' payouts when they believe that the probability of sustaining the current level of income is high. Firms that decrease dividends on the other hand, have higher past volatility than other firms, and this volatility is on the rise. The most recent work is by Elmi and Muturi (2016) assess effects of profitability on dividend payout by commercial and services firms listed on the Nairobi Securities Exchange (NSE) in Kenya which used 10 years $(2005-2014)$ data for the study; both primary and secondary data were applied. They posit that respondents were of the view that when the profitability of the company reduces, the company reduces its dividend payout. They also found that respondents agreed that dividend decisions convey information about the company profitability to investors. Moreover, study results revealed that when the profitability of the surveyed firms suffers, the dividends payable are reduced. Similarly, study results show that when the surveyed companies project high profitability growth, they show that to their investors through paying high dividends. However, the results found no significant effect of profitability on dividend payout, despite the fact that 
profitability had a positive effect on dividend payout. This implies that changes in profitability are not expected to have significant effect on dividend payout. However, when the profitability of the company reduces, the company reduces its dividend payout though not significantly. Dividend decisions however, convey information about the company profitability to investors.

In spite of huge research work on dividend policy; financial analyst, economists and managers of corporation still face the problem of dividend policy (Black, 1976). In this regard this research tries to unfold the relationship between dividend payout ratio and corporate profitability for the listed consumer goods manufacturing firms in Nigeria Stock Exchange.

Return on Assets (ROA) is calculated as: Profit after Interest and Tax/Total Assets

Return on Equity (ROE) is calculated as: Net Profit After Tax/Shareholders' Equity

$H_{O I}$ : Dividend payout has no significant impact on the ROA of listed consumer goods manufacturing firms in Nigeria

$H_{O 2}$ : Dividend payout has no significant impact on ROE of the listed consumer goods manufacturing firms in Nigeria

\section{Methodology and Robustness Test}

For the purpose of this study, correlational research design was used since the study is quantitative, longitudinal balanced panel data from secondary sources extracted from the sampled firms audited financial report within the period of study is utilized. Multiple regressions were used as a technique for data analysis via SPSS 16.0. The population of the study comprises of all 22 quoted consumer goods manufacturing firms on the Nigerian Stock Exchange as at 1st January, 2008 which have not been delisted as at 31 st December, 2014. In view of the nature of the model used in this study, a filter is employed to eliminate some of the firms that do not have complete records of all the data needed for measuring the variables of the study within the period (2008-2014). Consequently, 17 firms are eliminated leaving 10 firms.

Considering the dependent, independent and control variables employed in the study, the researcher modeled the study as follows:

Where the function of firm profitability is given by

Firm profitability $=\mathrm{f}\{\mathrm{ROA}$ and $\mathrm{ROE}\}$

The regression model that is to be used for the whole sample will be operationalized as follows:

$\mathrm{ROA}_{\mathrm{it}}=\beta_{0 \mathrm{it}}+\beta_{1} \mathrm{DPR}_{\mathrm{it}}+\varepsilon_{\mathrm{it}}$

$\mathrm{ROE}_{\mathrm{it}}=\beta_{0 \mathrm{it}}+\beta_{1} \mathrm{DPR}_{\mathrm{it}}+\varepsilon_{\mathrm{it}}$

The model will be operational as follows for the subsample:

$\mathrm{ROA}_{\mathrm{it}}=\beta_{0 \mathrm{it}}+\beta_{1 \mathrm{it}} \mathrm{DPR}_{\mathrm{it}}+\beta_{2 \mathrm{it}} \mathrm{REPS}_{\mathrm{it}}+\beta_{3 \mathrm{it}} \mathrm{GROWTH}_{\mathrm{it}}+\varepsilon_{\mathrm{it}}$

$\mathrm{EPS}_{\mathrm{it}}=\beta_{0 \mathrm{it}}+\beta_{1 \mathrm{it}} \mathrm{DPR}_{\mathrm{it}}+\beta_{2 \mathrm{it}} \mathrm{REPS}_{\mathrm{it}}+\beta_{3 \mathrm{it}} \mathrm{GROWTH}_{\mathrm{it}}+\varepsilon_{\mathrm{it}}$

Where:

DPR $=$ Dividend Payout Ratio

$\beta_{\mathrm{o}}=$ Intercept

ROA $=$ Return on Assets

$\mathrm{ROE}=$ Return on Equity

REPS $=$ Retain Earning Per Share

GROWTH $=$ Difference between the current year sale and previous year sales divided by previous year sales $\varepsilon=$ Residual or error term.

\section{Results and discussion}

The hypotheses were tested adopting fixed effect and random effects and decision to reject the null hypothesis were based on the panel least squares for the hypothesis. The tests were aided with SPSS version 16.0. The test of adequacy of fixing the effects of the time and cross-sectional specific effects; panel least squares for random effects estimators (if any). The hypotheses for this study were tested and analyzed by the researcher.

Table 1: Descriptive Statistics

\begin{tabular}{|c|c|c|c|c|c|}
\hline & $\mathrm{N}$ & Minimum & Maximum & Mean & Std. Deviation \\
\hline ROA & 70 & -.07 & .38 & .0809 & .07556 \\
\hline ROE & 70 & -.25 & .67 & .1841 & .15365 \\
\hline DPR & 70 & -.18 & 1.26 & .4779 & .30006 \\
\hline REPS & 70 & -2.07 & 12.37 & 1.1526 & 1.99454 \\
\hline Growth & 70 & -2.57 & .90 & .0624 & .35629 \\
\hline Valid N (listwise) & 70 & & & & \\
\hline
\end{tabular}

Sources: SPSS 16.0 Output 2016 
Table 1 indicates that ROA of consumer goods firms of the NSE within 2007-2014 lies between $7 \mathrm{k}$ and $38 \mathrm{kobo}$ and ROE are between $-25 \mathrm{k}$ and $67 \mathrm{kobo}$. Dividend payout ratio (DPR) of consumer goods firms of the Nigeria Stock Exchange (NSE) are between -.18 and 1.26, retain earnings per share (REPS) are between - 2.07 and $\$ 12.37$ while growth range from -2.57 to 0.90 signifying a combination of firm having high and low variability of earning within the period.

The data description also reveals that ROA, ROE, DPR, REPS and Growth are all at average of $.0809, .1841, .4779,1.1526$ and 0.0624 respectively. This can be supported by their respective standard deviation of $.07556, .15365, .3006,1.99454$ and .35629 . Overall, the standard deviations of all variables do not differ greatly from their respective mean which indicates that the data are normally distributed.

Table 2: Correlations

\begin{tabular}{lcccrr}
\hline & ROA & ROE & DPR & REPS & Growth \\
\hline ROA & 1 & & & & \\
ROE & $.908^{* *}$ & 1 & & & \\
DPR & $.574^{* *}$ & $.564^{* *}$ & 1 & & \\
REPS & -.052 & .056 & $-.290^{*}$ & 1 \\
Growth & .171 & $.259^{*}$ & .183 & .085 & 1 \\
\hline
\end{tabular}

**. Correlation is significant at the 0.01 level (2-tailed).

*. Correlation is significant at the 0.05 level (2-tailed).

The table 2 above is a correlation matrix table which shows the relationship between all pairs of variable in the regression model. The result reveals a positive correlation between all independent variables and the dependent variable (ROA) with the exception of retaining earnings per share (REPS) that shows negative relationship. As for dependent variable ROE has positive relationship with all independent variables. But the positive relationship is only strong as regard to dividend payout ratio (DPR) both dependent variables. These correlation necessitate for a further robustness test to check for the possibility of multicollinaerity using the variance inflation factor (VIF) reveals the absence of it as all factors are below 10 and tolerance values are below 1

Table 3: Model summary of the study

\begin{tabular}{|c|c|c|c|c|c|c|}
\hline & \multicolumn{3}{|c|}{ ROA } & \multicolumn{3}{|c|}{ ROE } \\
\hline & Coefficient & t-value & p-value & Coefficient & t-value & $\overline{p \text {-value }}$ \\
\hline Constant & .003 & .182 & .856 & .013 & .407 & .685 \\
\hline DPR & .151 & 5.624 & 0.000 & .310 & 5.859 & .000 \\
\hline $\mathrm{RE}$ & .004 & 0.114 & 0.269 & .017 & 2.166 & .034 \\
\hline Growth & .011 & .498 & .620 & .056 & 1.303 & .197 \\
\hline $\mathrm{R}^{2}$ & 0.347 & & & .387 & & \\
\hline AJD $R^{2}$ & 0.317 & & & .359 & & \\
\hline F-stat. & 11.674 & & & 13.888 & & \\
\hline F-sig & & & 0.000 & & & 0.000 \\
\hline $\mathrm{D} / \mathrm{W}$ & & & 1.961 & & & 2.166 \\
\hline
\end{tabular}

Source: SPSS 16.0 Output 2017

$\mathrm{ROA}_{\mathrm{it}}=.003+.151\left(\mathrm{DPR}_{\mathrm{it}}\right)+0.004\left(\mathrm{RE}_{\mathrm{it}}\right)+.011\left(\mathrm{GR}_{\mathrm{it}}\right)+0.06245$

$\mathrm{ROE}_{\mathrm{it}}=0.182+5.624\left(\mathrm{DPR}_{\mathrm{it}}\right)+0.114\left(\mathrm{RE}_{\mathrm{it}}\right)+0.498\left(\mathrm{GR}_{\mathrm{it}}\right)+.359$

The autocorrelation among regression model residuals have been tested using Durbin-Watson factors. If Durbin-Watson factors are between (1) and (3) there is no autocorrelation problem

(Alsaeed, 2005). As shown in table (4), all Durbin-Watson factors are between (1) and (3), so there is no autocorrelation problem in the regression models.

ROA

The cumulative $\mathrm{R}^{2}(0.317)$ which is the total variation of determination gave the proportion of the total variation in the dependent variable explained by the independent variable jointly. Hence, it signifies that $32 \%$ of the total variation in ROA of listed consumer goods in Nigeria was caused by their dividend payout ratio (DPR), retain earnings per share (REPS) and growth.

The F-statistics of 11.674 which is significant at $1 \%$ indicates that the ROA and firm dividend policy model was fit. This indicates that the model is fit and the independent variables are properly selected, combined and used. This implies that for any changes in dividend policy of listed consumer goods companies in Nigeria their ROA will be directly affected. The value of F-statistics which is statistically significant at a level of 0.000 , means that there is a $99.9 \%$ probability that the relationship among the variables was not due to mere change.

The table 3 shows that there is a positive significant relationship between dividend payout ratio (DPR) and ROA of listed consumer goods companies in Nigeria. This can be observed from the unstandardized value of beta 
coefficient of 0.151 with $\mathrm{P}$ value 0.000 which is significant at $1 \%$. This indicates that the DPR is positively impacted on the ROA of listed consumer goods companies in Nigeria. The implication of the result is that, higher DPR is better at increasing the ROA of listed consumer goods companies in Nigeria.

Consequently, the result produce a basis for rejecting the first null hypothesis formulated which presumed that DPR has no significant effect on ROA of listed consumer goods companies in Nigeria. This supported dividend relevant theory, Miller and Rock (1985) and Enekwe, Nweze and Agu (2009). It is also in-line with the findings in Khan (2012), Musiega et al (2013), Sarhandi et al (2015) and others that conclude that DPR is positively and significantly associated with ROA and contradicts the finding of Hasan et al (2015) who documented that DPR is negatively significantly related to ROA.

Again, the retain earnings per share (REPS) and growth has no significant impact on the ROA of listed consumer goods companies in Nigeria as both are not significant even at $10 \%$ significant level. This implies that, highly REPS and growth of listed consumer goods companies in Nigeria has no impact on ROA. This also serves as a justification for the non rejection of the second and third null hypothesis which presumed that leverage has no significant impact on ROA of consumer goods companies in Nigeria.

ROE

The cumulative $\mathrm{R}^{2}(0.359)$ which is the total variation of determination gave the proportion of the total variation in the dependent variable explained by the independent variable jointly. Hence, it signifies that $36 \%$ of the total variation in ROE of listed consumer goods in Nigeria was caused by their dividend payout ratio (DPR), retain earnings per share (REPS) and growth.

The F-statistics of 13.888 which is significant at $1 \%$ indicates that the ROE and firm dividend policy model was fit. This indicates that the model is fit and the independent variable are properly selected, combined and used. This implies that for any changes in dividend policy of listed consumer goods companies in Nigeria their ROE will be directly affected. The value of F-statistics which is statistically significant at a level of 0.000 , means that there is a $99.9 \%$ probability that the relationship among the variable was not due to mere change.

The table 3 shows that there is a positive significant relationship between dividend payout ratio (DPR) and ROE of listed consumer goods companies in Nigeria. This can be observed from the unstandardize value of beta coefficient of 0.310 with $\mathrm{P}$ value 0.000 which is significant at $1 \%$. This indicates that the DPR is positively impacted on the ROE of listed consumer goods companies in Nigeria. The implication of the result is that, for every $\$ 1$ increase in DPR of listed consumer goods companies in Nigeria, ROE will increase by 31 Kobo.

Consequently, the result produce a basis for rejecting the first null hypothesis formulated which presumed that DPR has no significant effect on ROE of listed consumer goods companies in Nigeria. This is consistent with dividend relevant theory, Miller and Rock (1985) and Enekwe, Nweze and Agu (2009).This is line with the finding of Enkwe et al (2009), Khan (2012), Musiega et al (2013), Sarhandi et al (2015) and others that found that DPR is positively and significantly associated with ROE and contradicts the finding of Hasan et al (2015) who documented that DPR is negatively significantly related to ROE.

Again, the Retain Earnings per Share (REPS) and growth has no significant impact on the ROE of listed consumer goods companies in Nigeria as both are not significant even at $10 \%$ significant level. This implies that, higher or lower REPS and growth of listed consumer goods companies in Nigeria has no impact on ROE. This also serve as a justification for non rejection of the second and third null hypothesis which presumed that REPS and growth has no significant impact on ROE of consumer goods companies in Nigeria.

\section{Conclusion and Recommendation}

The central objective of this research is to empirically find out the relationship between dividend payout and corporate profitability of the quoted consumer goods companies on Nigeria Stock Exchange. Based on the results, it could be found that the impact of dividend payout on corporate profitability measured by ROA and ROE is positive and statistically significant at $1 \%$ significant level. As the ultimate objective of a corporate is to maximize shareholders' wealth, hence the firm value, firm mangers should design and implement dividend policy that will enhance the corporate profitability and shareholders wealth.

\section{REFERENCES}

Abdullah, M. A. M., \& Thafani, F. (2014). Impact of Dividend Payout on Corporate Profitability : Evident from Colombo. Advances in Economics and Business Management (AEBM), 1(1), 27-33.

Ajanthan, A. (2013). The Relationship between Dividend Payout and Firm Profitability : A Study of Listed Hotels and Restaurant Companies in Sri Lanka, 3(6), 1-6.

Alsaeed, K., (2005). The Association between Firm-specific Characteristics and disclosure: the case of Saudi Arabia. The Journal of American Academy of Business, 7(1), 310-321.

Black, F. (1976). The dividend puzzle. The Journal of Portfolio Management, 2(2): p. 5-8.

Elmi, M. A., \& Muturi, W. M. (2016). Effects Of Profitability On Dividend Payout By Commercial And Services Firms Listed In The Nairobi Securities Exchange Mohamed. European Journal of Business and Social 
Sciences, 5(2), 160-167.

Enekwe, C. I., Nweze, A. U., \& Agu, C. I. (2009). The Effect of Dividend Payout on Performance Evaluation: Evidence of Quoted Cement Companies in Nigeria. European Journal of Accounting, Auditing and Finance Research, 3(11), 40-59.

Fama, E. F. \& French, K. R. (2001). Disappearing Dividends: Changing Firm Characteristics or Lower Propensity to Pay.Journal of Financial Economics, 60, 3-43.

Lie, E. (2005). Operating Performance Following Dividend Decreases and Omissions.Journal of Corporate Finance, 12 (1), $27-53$

Gill, A., Biger, N., Tibrewala, R., \& Palmer, S. (2010). Determinants of Dividend Payout Ratios : Evidence from United States. The Open Business Journal, 3(1), 8-14.

Kumar, L. (online) makemynote.weebly.com Retreived 27 $7^{\text {th }}$ Jan. 2017

Hasan, M., Ahmad, M. I., Rafiq, M. Y., \& Rehman, R. U. (2015). Dividend Payout Ratio and Firm's Profitability . Evidence from Pakistan. Theoretical Economics Letter, 5(3), 441-445.

Holder, M. F., Langrehr, \& Hexter, J. (1998). Dividend Policy Determinants: An Investigation of the Influences of Stakeholder Theory. Financial Management Journal, 2(1), 73-82.

Khan, K. I. (2012). Effect of Dividends On Stock Prices. Management, 2(5), 141-148.

Khan, S., Anuar, M. A., Ramakrishnan, S., Malik, M. F., \& Johor, S. (2015). A Study on the Effect of Dividend Payout Ratio and Firm. Sci.Int(Lahore), 27(2), 1403-1406.

Malik, F., Sajid, G., Khan, M. T., Rehman, S. U., \& Khan, M. (2013). Factors Influencing Corporate Dividend Payout Decisions of Financial and Non-Financial Firms. Research Journal of Finance and Accounting, 4(1), $35-47$.

Miller, M.H. and K. Rock, (1985), Dividend Policy under Asymmetric information, Journal of Finance, 40(4), 1031-1051.

Musiega, M. G., Alala, O. B., Douglas, M., Christopher, M. O., \& Robert, E. (2013). Determinants Of Dividend Payout Policy Among Non-Financial Firms On Nairobi Securities. International Journal Of Scientific \& Technology Research Volume,2(10), 253-266.

Okpara, F. \& Chigozie, G. (2010). A Diagnosis of the Determinant of Dividend Pay-Out Policyin Nigeria: A Factor Analytical Approach. American Journal of Scientific Research(8), 57-67.

Rafique, M. (2012). Factors Affecting Dividend Payout : Evidence From Listed Non-Financial Firms of Karachi Stock Exchange. Business Management Dynamics, 1(11), 76-92.

Rehman, A., \& Takumi, H. (2012). Determinants of Dividend Payout Ratio: Evidence from Karachi Stock Exchange (KSE). Journal of Contemporary Issues in Business Research, 1(1), 20-27.

Samuel, K. \& Edward, M. (2011). Dividend Policy and Bank Performance in Ghana.International Journal of Economics and Finance, 3(4), 76-83

Sarhandi, B. R., Farooq, K., Iqbal, M. Q., Mukhtar, A., \& Amir, S. (2015). The Relationship Between Dividend Payout Ratio With Revenue, Liabilities And Expenses: An Empirical Study Of KSE Listed Non-Financial Firms. International Journal of Scientific \& Engineering Research, 6(3), 476-482. 


\section{Appendix}

Descriptive Statistics

\begin{tabular}{|l|r|r|r|r|r|}
\hline & N & Minimum & Maximum & Mean & Std. Deviation \\
\hline ROA & 70 & -.07 & .38 & .0809 & .07556 \\
ROE & 70 & -.25 & .67 & .1841 & .15365 \\
DPR & 70 & -.18 & 1.26 & .4779 & .30006 \\
REPS & 70 & -2.07 & 12.37 & 1.1526 & 1.99454 \\
Growth & 70 & -2.57 & .90 & .0624 & .35629 \\
Valid N (listwise) & 70 & & & & \\
\hline
\end{tabular}

\section{Correlations}

\begin{tabular}{|cc|c|c|c|c|c|}
\hline & & ROA & R0E & DPR & REPS & Growth \\
\hline ROA & Pearson Correlation & 1 & $.908^{* *}$ & $.574^{* *}$ & -.052 & .171 \\
& Sig. (2-tailed) & & .000 & .000 & .669 & .158 \\
& $\mathrm{~N}$ & 70 & 70 & 70 & 70 & 70 \\
\hline R0E & Pearson Correlation & $.908^{* *}$ & 1 & $.564^{* *}$ & .056 & $.259^{*}$ \\
& Sig. (2-tailed) & .000 & & .000 & .643 & .031 \\
& $\mathrm{~N}$ & 70 & 70 & 70 & 70 & 70 \\
\hline DPR & Pearson Correlation & $.574^{* *}$ & $.564^{* *}$ & 1 & $-.290^{*}$ & .183 \\
& Sig. (2-tailed) & .000 & .000 & & .015 & .129 \\
& N & 70 & 70 & 70 & 70 & 70 \\
\hline REPS & Pearson Correlation & -.052 & .056 & $-.290^{*}$ & 1 & .085 \\
& Sig. (2-tailed) & .669 & .643 & .015 & & .484 \\
& N & 70 & 70 & 70 & 70 & 70 \\
\hline Growth & Pearson Correlation & .171 & $.259^{*}$ & .183 & .085 & 1 \\
& Sig. (2-tailed) & .158 & .031 & .129 & .484 & 70 \\
\hline
\end{tabular}

**. Correlation is significant at the 0.01 level (2-tailed)

*. Correlation is significant at the 0.05 level (2-tailed).

ROA

Model Summary

\begin{tabular}{|c|c|c|c|c|c|c|c|c|c|c|}
\hline \multirow[b]{2}{*}{ Model } & \multirow[b]{2}{*}{$\mathrm{R}$} & \multirow[b]{2}{*}{ R Square } & \multirow[b]{2}{*}{$\begin{array}{c}\text { Adjusted R } \\
\text { Square }\end{array}$} & \multirow[b]{2}{*}{$\begin{array}{l}\text { Std. Error of } \\
\text { the Estimate }\end{array}$} & \multicolumn{5}{|c|}{ Change Statistics } & \multirow[b]{2}{*}{ Durbin-Watson } \\
\hline & & & & & $\begin{array}{c}\text { R Square } \\
\text { Change }\end{array}$ & F Change & df1 & $\mathrm{df} 2$ & $\begin{array}{c}\text { Sig. F } \\
\text { Change }\end{array}$ & \\
\hline 1 & $.589^{\mathrm{a}}$ & .347 & .317 & .06245 & .347 & 11.674 & 3 & 66 & .000 & 1.961 \\
\hline
\end{tabular}

a. Predictors: (Constant), Growth, Retained Earnings, Dividend Payout Ratio

b. Dependent Variable: Return on Assets 
ANOVA $^{b}$

\begin{tabular}{|ll|r|r|r|r|r|}
\hline Model & Sum of Squares & Df & Mean Square & F & Sig. \\
\hline 1 & Regressio & .137 & 3 & .046 & 11.674 & $.000^{\mathrm{a}}$ \\
$\mathrm{n}$ & .257 & 66 & .004 & & \\
& Residual & .394 & 69 & & & \\
& Total & & & & \\
& & & & & & \\
\end{tabular}

a. Predictors: (Constant), Growth, Retained Earnings, Dividend Payout Ratio

b. Dependent Variable: Return on Assets

Coefficients $^{\mathbf{a}}$

\begin{tabular}{|c|c|c|c|c|c|c|c|c|}
\hline \multirow{2}{*}{\multicolumn{2}{|c|}{ Model }} & \multicolumn{2}{|c|}{$\begin{array}{l}\text { Unstandardized } \\
\text { Coefficients }\end{array}$} & \multirow{2}{*}{$\begin{array}{c}\begin{array}{c}\text { Standardized } \\
\text { Coefficients }\end{array} \\
\text { Beta }\end{array}$} & \multirow[b]{2}{*}{$\mathrm{T}$} & \multirow[b]{2}{*}{ Sig. } & \multicolumn{2}{|c|}{$\begin{array}{c}\text { Collinearity } \\
\text { Statistics }\end{array}$} \\
\hline & & B & Std. Error & & & & Tolerance & VIF \\
\hline \multirow[t]{4}{*}{1} & (Constant) & .003 & .016 & & .182 & .856 & & \\
\hline & Dividend Payout Ratio & .151 & .027 & .599 & 5.624 & .000 & .873 & 1.146 \\
\hline & Retained Earnings & .004 & .004 & .117 & 1.114 & .269 & .896 & 1.116 \\
\hline & Growth & .011 & .022 & .051 & .498 & .620 & .946 & 1.057 \\
\hline
\end{tabular}

a. Dependent Variable: Return on Assets

ROE

Model Summary ${ }^{b}$

\begin{tabular}{|c|c|c|c|c|c|c|c|c|c|c|}
\hline \multirow[b]{2}{*}{ Model } & \multirow[b]{2}{*}{$\mathrm{R}$} & \multirow[b]{2}{*}{ R Square } & \multirow[b]{2}{*}{$\begin{array}{c}\text { Adjusted R } \\
\text { Square }\end{array}$} & \multirow{2}{*}{$\begin{array}{l}\text { Std. Error } \\
\text { of the } \\
\text { Estimate }\end{array}$} & \multicolumn{5}{|c|}{ Change Statistics } & \multirow[b]{2}{*}{ Durbin-Watson } \\
\hline & & & & & $\begin{array}{l}\text { R Square } \\
\text { Change }\end{array}$ & F Change & df1 & $\mathrm{df} 2$ & $\begin{array}{c}\text { Sig. F } \\
\text { Change }\end{array}$ & \\
\hline 1 & $.622^{\mathrm{a}}$ & .387 & .359 & .12300 & .387 & 13.888 & 3 & 66 & .000 & 2.166 \\
\hline
\end{tabular}

a. Predictors: (Constant), Growth, Retained Earnings, Dividend Payout Ratio

b. Dependent Variable: Return on Equity

ANOVA

\begin{tabular}{|ll|r|r|r|r|r|}
\hline Model & & Sum of Squares & df & Mean Square & F & Sig. \\
\hline 1 & Regression & .630 & 3 & .210 & 13.888 & $.000^{\mathrm{a}}$ \\
& Residual & .999 & 66 & .015 & & \\
& Total & 1.629 & 69 & & & \\
\hline
\end{tabular}

a. Predictors: (Constant), Growth, Retained Earnings, Dividend Payout Ratio

b. Dependent Variable: Return on Equity

\section{Coefficients $^{\mathrm{a}}$}

\begin{tabular}{|c|c|c|c|c|c|c|c|c|}
\hline \multirow{2}{*}{\multicolumn{2}{|c|}{ Model }} & \multicolumn{2}{|c|}{$\begin{array}{l}\text { Unstandardized } \\
\text { Coefficients }\end{array}$} & \multirow{2}{*}{$\begin{array}{c}\text { Standardized } \\
\text { Coefficients } \\
\text { Beta }\end{array}$} & \multirow[b]{2}{*}{$\mathrm{t}$} & \multirow[b]{2}{*}{ Sig. } & \multicolumn{2}{|c|}{ Collinearity Statistics } \\
\hline & & B & Std. Error & & & & Tolerance & VIF \\
\hline \multirow[t]{4}{*}{1} & (Constant) & .013 & .032 & & .407 & .685 & & \\
\hline & Dividend Payout Ratio & .310 & .053 & .604 & 5.859 & .000 & .873 & 1.146 \\
\hline & Retained Earnings & .017 & .008 & .220 & 2.166 & .034 & .896 & 1.116 \\
\hline & Growth & .056 & .043 & .129 & 1.303 & .197 & .946 & 1.057 \\
\hline
\end{tabular}

a. Dependent Variable: Return on Equity 